\title{
Seeking Applicants for SMST Founders' Grant!
}

The International Organization on Shape Memory and Superelastic Technologies (SMST), an affiliate society of ASM International, is seeking applications for the 2019 SMST Founders' Grant. The intent of the SMST Founders' Grant is to provide funding for early, exploratory research related to shape memory and superelasticity. It is expected that the funds will be used as a "seed grant," used to test a concept and lay a foundation for obtaining further funding from industry or government agencies. The grant, which is financially funded in 2019 by Dr. T. W. Duerig, includes a stipend up to $\$ 50,000$. Deadline to apply is January 11, 2019.

Please continue to check the ASM International website for further details: https://www.asminternational.org/web/ smst/smst-fellowship or contact carrie.wilson@asminter national.org. 